\title{
Chest X-Ray Assessment is Incomplete without the Lateral View [Letter]
}

This article was published in the following Dove Press journal:

Advances in Medical Education and Practice

\section{Bruce Rothschild (iD}

IU Health, Muncie, IN 47303, USA

Correspondence: Bruce Rothschild IU Health, Muncie, IN 47303, USA

Tel +I-7856I5I523

Email Spondylair@gmail.com

\section{Dear editor}

The article by Sait and Tombs ${ }^{1}$ represents an important contribution to the preparation of students for a career in medicine. The perhaps not so subliminal message is that clinicians (eg, primary care and specialty providers) need to routinely examine and be able to interpret primary data (eg, x-rays), not just rely upon another physician's (eg, radiologist's) report. No one bats $100 \%$, so additional assessments are not only quite reasonable, but essential. The clinician has an advantage because he or she has pertinent clinical information (often not fully shared with the radiologist) and the x-ray is part of a targeted diagnostic evaluation. The radiologist is also advantaged because he/she pursues systematic x-ray reviews, with less distraction (from completeness of that evaluation) by clinical information. My cardiologist mentor, Dave Spodick, once promoted examination of EKGs before assessing reported clinical information and repeating that review, with information directing specific attention. I believe that approach has merit for radiology. The combination/collaboration of radiologist and primary care physician interpretations mirrors that approach and is certainly worth encouragement.

The article by Sait and Tombs ${ }^{1}$ provides a useful approach to assessment of posterior-anterior chest x-rays, but that is only half the challenge. Just as important is to also include evaluation of the lateral chest x-ray, a source of clinicallypertinent information that often eludes radiologist's reports. ${ }^{2-5}$ Evaluation for the normally progressive vertebral (anterior to the vertebrae) darkening (loss of radioopacity) as one visually descends the vertebral column is critical. Persistence of opacity suggests the presence of a lower lobe infiltrate, often not apparent on posterior-anterior x-ray views. ${ }^{4,5}$ Assessment of vertebral body internal defects and shape is valuable for identification of the anterior margin scalloping that is characteristically produced by aortic aneurysms and for lytic or blastic lesions related to neoplasia and infection (eg, tuberculosis or brucellosis). ${ }^{5}$ While aneurysms, neoplasia, and infection may not be common, suggestive findings are often not visualized on posterior-anterior chest x-rays and their diagnosis, delayed if only anterior-posterior view $\mathrm{x}$-rays are assessed. Perhaps the most important contribution of the lateral chest $\mathrm{x}$-ray is affording the opportunity to recognize osteoporosis on the basis of vertebral compression fracture. ${ }^{5}$ Notation of reduction of the height of the anterior aspect of a vertebra (compared with its posterior height) identifies the presence of a compression fracture. Such recognition is cost-effective, obviating 
the need for further diagnostic testing and the additional radiation exposure associated with such techniques.

Collaboration between the radiologist and clinician provides an important component in the evaluation of the patients we serve. Such an approach can only be advantaged if clinicians provide appropriate information to the radiologist and are comfortable with evaluating the x-rays we request.

\section{Disclosure}

The author reports no conflicts of interest in this communication.

\section{References}

1. Sait S, Tombs M. Teaching medical students how to interpret chest $\mathrm{X}$-rays: the design and development of an e-learning resource. Advan Med Ed Pract. 2021;12:123-132. doi:10.2147/AMEP.S280941

2. Osman F, Williams I. Should the lateral chest radiograph be routinely performed? Radiography. 2014;20(2):162-166. doi:10.1016/j. radi.2013.10.006

3. Brenden C, Wallis C, Owens CM, Ridout DA, Dinwiddie R. The Chrispin Normal score in cystic fibrosis: doing away with the lateral view. Europ Resp J. 2005;26(5):894-897. doi:10.1183/ 09031936.05.00059105

4. Feigin DS. Lateral chest radiograph A systematic approach. Acta Radiol. 2010;17(12):1560-1566. doi:10.1016/j.acra.2010.07.004

5. Rothschild BM. The transcendental lateral chest x-ray. Radiography. 2014;20(3):21. doi:10.1016/j.radi.2014.05.008

Dove Medical Press encourages responsible, free and frank academic debate. The content of the Advances in Medical Education and Practice 'letters to the editor' section does not necessarily represent the views of Dove Medical Press, its officers, agents, employees, related entities or the Advances in Medical Education and Practice editors. While all reasonable steps have been taken to confirm the content of each letter, Dove Medical Press accepts no liability in respect of the content of any letter, nor is it responsible for the content and accuracy of any letter to the editor.

Advances in Medical Education and Practice

Dovepress

\section{Publish your work in this journal}

Advances in Medical Education and Practice is an international, peerreviewed, open access journal that aims to present and publish research on Medical Education covering medical, dental, nursing and allied health care professional education. The journal covers undergraduate education, postgraduate training and continuing medical education including emerging trends and innovative models linking education, research, and health care services. The manuscript management system is completely online and includes a very quick and fair peer-review system. Visit http://www.dovepress.com/testimonials.php to read real quotes from published authors. 